\title{
Association between whole grain intake and breast cancer risk: a systematic review and meta-analysis of observational studies

Yunjun Xiao ${ }^{1 \dagger}$, Yuebin $\mathrm{Ke}^{1 \dagger}$, Shuang $\mathrm{Wu}^{1}$, Suli Huang ${ }^{1}$, Siguo $\mathrm{Li}^{1}$, Ziquan $\mathrm{Lv}^{1}$, Eng-kiong Yeoh², Xiangqian Lao ${ }^{2}$, Samuel Wong ${ }^{2}$, Jean Hee Kim², Graham A. Colditz ${ }^{3}$, Rulla M. Tamimi ${ }^{4,5^{*}}$ and Xuefen Su²

\begin{abstract}
Background: Epidemiological studies have found that high whole grain intake may be associated with a reduced risk of breast cancer. However, the evidence has not been consistent. We conducted a meta-analysis to quantitatively assess the association between whole grain intake and breast cancer risk.

Methods: Relevant observational studies were identified by searching PubMed, Embase, Cochrane library databases, and Google Scholar through April 2017. Summary relative risk (RR) estimates were calculated using random-effects meta-analysis.

Results: A total of 11 studies, including 4 cohort and 7 case-control studies and involving 131,151 participants and 11,589 breast cancer cases, were included in the current meta-analysis. The pooled RR of breast cancer for those with high versus low whole grain intake was 0.84 (95\% confidence interval [CI]: 0.74 to $0.96, p=0.009 ; P^{2}=63.8 \%$, $p$ for heterogeneity $=0.002$ ). Subgroup analysis by study design found a significant inverse association in the

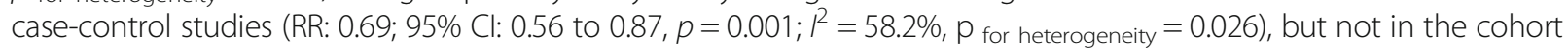
studies (RR, $0.96 ; 95 \% \mathrm{Cl}: 0.82$ to $1.14, p=0.69 ; P^{2}=66.7 \%$, $\mathrm{p}$ for heterogeneity $=0.029$ ). In addition, stratified analysis suggested that sample size could be a potential source of heterogeneity.

Conclusions: Results of the current meta-analysis suggest that high intake of whole grains might be inversely associated with a reduced risk of breast cancer, and the inverse association was only observed in case-control but not cohort studies. More large-scale cohort studies are needed to confirm the inverse association observed.
\end{abstract}

Keywords: Whole grain, Breast cancer, Observational studies, Meta-analysis

\section{Background}

Breast cancer is the most commonly diagnosed cancer among women worldwide. The incidence rate has been rising increasing over the past several decades [1]. On aggregate, each year 1.7 million women were diagnosed with breast cancer. Most well-established breast cancer risk factors, however, are not easily modifiable such as

\footnotetext{
* Correspondence: rulla.tamimi@channing.harvard.edu; xuefensu@cuhk.edu.hk

${ }^{\dagger}$ Yunjun Xiao and Yuebin Ke contributed equally to this work and as co-first authors ${ }^{4}$ Channing Division of Network Medicine, Brigham and Women's Hospital, Harvard Medical School, 181 Longwood Avenue, Boston, MA 02115, USA ${ }^{2}$ School of Public Health and Primary Care, Faculty of Medicine, School of Public Health, Prince of Wales Hospital, The Chinese University of Hong Kong, Room 508, Shatin, New Territories, Hong Kong, China Full list of author information is available at the end of the article
}

family history, age at menarche, age at menopause, and reproductive history. Therefore, diet, as a potentially modifiable factor, has been investigated intensively as a potential means for breast cancer prevention [2].

Grains are one of the major staple foods consumed globally and provide $56 \%$ of the energy and $50 \%$ of the protein intake [3]. They make up the largest proportion of recommended daily food intake in various dietary guidelines. Because of the important role of grains in most diets around the world, the health effects of grain consumption, and in particular whole grains, have attracted much research interest. Whole grains contain endosperm, germ, and bran, in contrast to refined grains, from which germ and bran was removed during the milling process. A high intake of whole grains has been associated with a reduced

(c) The Author(s). 2018 Open Access This article is distributed under the terms of the Creative Commons Attribution 4.0 International License (http://creativecommons.org/licenses/by/4.0/), which permits unrestricted use, distribution, and 
risk of type 2 diabetes [4-6], cardiovascular disease [7-9], and mortality $[8,10]$. In particular, whole grain is a primary source of dietary fiber, which has been associated with a reduced risk of various types of cancer [11]. Two recent meta-analyses reported an inverse association between dietary fiber and whole grain intake and the risk of colorectal cancer [12, 13]. A previous review of mostly case-control studies also reported that higher intake of whole grains was associated with a lower risk of several individual cancers, mainly of the digestive system [14].

The association between whole grain consumption and breast cancer risk has been investigated in previous epidemiological studies. Some have found a possible inverse association [15-21], whereas others have shown no clear association [22-25]. The inconsistent results may be due to different study designs, various dietary intake assessment methods, the amount of whole grain consumption in different study populations, and a range of confounding factors that were adjusted in previous studies. To our knowledge, no systematic review or meta-analysis has been performed to summarize the evidence from observational studies. We, therefore, conducted a meta-analysis to quantitatively evaluate the association between whole grain intake and breast cancer risk.

\section{Methods}

\section{Data sources and literature search}

We followed the guidelines of the Meta-analysis of Observation Studies in Epidemiology group (MOOSE) [26], and the PRISMA criteria guidelines [27], and filled the PRISMA Checklist (Additional file 1: Table S1). Databases including PubMed, EMBASE, Google Scholar, and Cochrane Library were searched through April 2017 for relevant articles that reported the association between whole grain intake and the risk of breast cancer. To avoid missing any relevant studies, we also searched the bibliographies of retrieved papers and recent reviews in the field. The following medical subject headings (MESH) and keywords were used in the literature search, including "grain" or "grains", "breast cancer" or "breast carcinoma". We conducted the literature search with combinations of ("grain" and "breast cancer"), or ("grain" and "breast carcinoma"), or ("grains" and "breast cancer"), or ("grains" and "carcinoma"), or (("grain" or "grains") and ("breast cancer" or "breast carcinoma")). No restrictions were imposed.

\section{Study selection}

Studies were eligible if they met the following inclusion criteria: 1) a case-control or cohort study; 2) assessed the association between whole grain intake and the risk of breast cancer; 3) breast cancer cases were diagnosed and verified by pathological biopsies or other standard methods, with controls being females without breast cancer; 4) reported relative risks (RRs) or odds ratios (ORs) and the corresponding 95\% confidence intervals (CIs) for the highest versus the lowest levels of whole grain intake.

Two reviewers independently screened the titles and abstracts of the searched papers and excluded the articles which did not meet the above-described inclusion criteria. For those which were difficult to determine the eligibility based on title and abstract review, the full-texts were obtained and reviewed. All disagreements were resolved by discussion to reach a consensus.

The search strategy identified 479 potentially relevant articles from the various databases, and 94 records were excluded because they were duplicates (Fig. 1). After title and abstract review based on the above inclusion criteria, 353 articles were further excluded. After reviewing the full texts of the remaining 32 articles, 21 papers were excluded, because 1) the studies were not case-control or cohort studies $(n=3) ;[10,12,28] 2)$ the studies did not assess the whole grain intake $(n=14)$; [29-42] or 3$)$ the cases included were not breast cancer cases $(n=4)$ [12, 43-45]. Eleven studies involving 131,151 participants and 11,589 breast cancer cases were included in the present meta-analysis.

\section{Data extraction and quality assessment}

Two reviewers independently extracted data on study characteristics and results by using a standard data collection form. Data extracted included: first author's last name; year of publication; country of origin; study design; sample size; mean age of study population; dietary assessment methods; types of whole grain; RRs, including hazard ratios (HRs), ORs or incidence density ratios (IDRs), with the corresponding 95\% CIs; and adjusted variables.

We also systematically assessed the study quality. Briefly, a 9-score system on the basis of the Newcastle Ottawa Scale (NOS) was used to assess the quality of included studies. Each study was evaluated on three broad criteria: 1) the proper selection of study population, 2) the comparability of the study groups, and 3) the ascertainment of the exposure or outcome of interest. Two reviewers independently assessed the quality of each study. Studies scored greater or equal to7 (out of a maximum 9 points) were considered to be high quality studies. Any discrepancies in data extraction and quality assessment between the reviewers were resolved by consensus.

\section{Statistical analyses}

RR was used as a common measure of the association between whole grain intake and the risk of breast cancer. HRs, ORs, or IDRs were considered as estimates of RR. To calculate summary RR and its $95 \% \mathrm{CI}$, we pooled the results by using the random-effects meta-analysis [46]. The random-effects method was chosen a priori because 


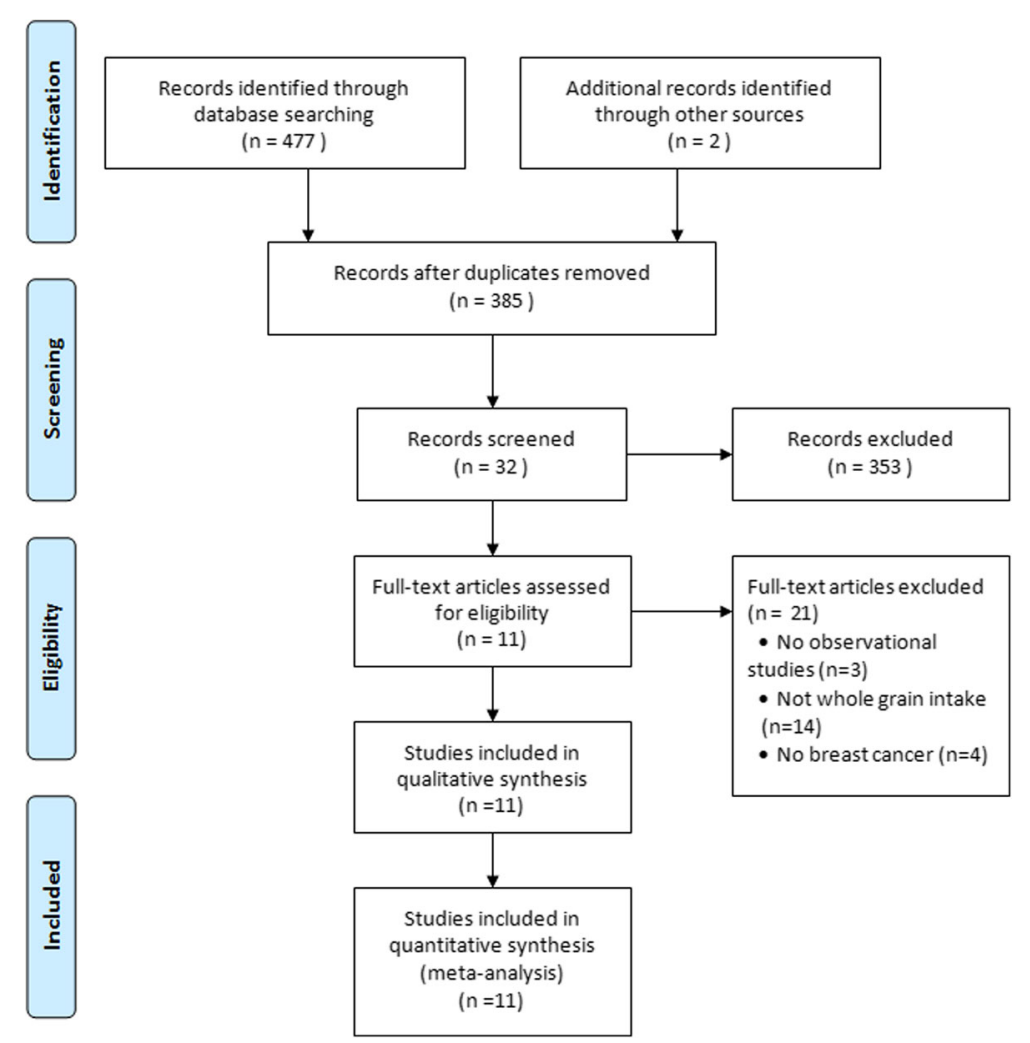

Fig. 1 Flow chart of study selection. Flow chart shows literature search for whole grain intake in relation to risk of breast cancer

of the anticipated clinical heterogeneity and because it is considered as more conservative than the fixed-effects method, as it accounts for both within- and between-study heterogeneity [47]. Heterogeneity across studies was evaluated by using the $\mathrm{Q}$ statistic with a conservative $p$ value $<0.10$ considered as statistically significant. We also calculated the $I^{2}$ statistic, which describes the proportion of total variation across studies which was attributable to heterogeneity rather than chance alone; an $I^{2}$ value greater than $50 \%$ indicated at least moderate heterogeneity [48]. Dose response relationship between whole grain intake and risk of breast cancer was analyzed by random-effects model and meta-regression with whole grain intake as an continuous variable. Furthermore, we assessed the influence of each individual study on the overall risk estimate by excluding one study at a time. Because characteristics of participants, and adjustments for confounding factors were not consistent across studies, we further conducted several sensitivity and stratified analyses to explore possible sources of heterogeneity and to examine the influence of various factors on the overall risk estimate. Subgroup analyses were performed by study design, sample size, publication year, numbers of adjusted variables, and quality scores of studies. Meta-regression analyses was used to evaluate the association of whole grain intake and risk of breast cancer between the subgroups.
Potential publication bias was evaluated by visual inspection of the Begg funnel plots in which the log RRs were plotted against their standard errors (SEs). We also performed the Begg rank correlation test and Egger linear regression test at the $p<0.10$ level of significance [49, 50]. All analyses were performed using STATA version 11.0 (Stata Corp LP, College Station, Texas). $p$ value $<0.05$ was considered statistically significant, except those specified otherwise.

\section{Results}

\section{Study characteristics}

The 11 included studies were published between 1987 and 2016, among which four were cohort studies $[15,19,22,23]$ and seven were case-control studies $[16-18,20,21,24,25]$ (Table 1). Two studies were conducted in the USA $[15,22]$, two in Italy [21, 24], and one in Greece [16], Iran [18], Denmark [23], German [20], Korea [17], Sweden [19], and Switzerland [25], respectively. The age of the participants ranged from 25 to 75 . The studies were adjusted for a wide range of potential confounding factors, including age, BMI, menopausal status, family history of breast cancer, hormone use, physical activity, smoking, energy intake, etc. The type and dose of whole grain intake and the relative risk of breast cancer are presented in Table 2. 
Table 1 Descriptions of the studies included in the systematic review and meta-analysis of whole grain intake and breast cancer risk

\begin{tabular}{|c|c|c|c|c|c|}
\hline Study & Location & Design & Sample size & Age & Diet-assessment method \\
\hline $\begin{array}{l}\text { Farvid et al., } \\
2016 \text { [15] }\end{array}$ & $\begin{array}{l}\text { United } \\
\text { States }\end{array}$ & $\begin{array}{l}\text { NHSII } \\
\text { Cohort (22) }\end{array}$ & $\begin{array}{l}44,263(3235 \\
\text { cases) }\end{array}$ & $36 \pm 5$ & $\begin{array}{l}\text { Adult diet was evaluated } \\
\text { using FFQ (130 items, past year); } \\
\text { Adolescent diet was evaluated } \\
\text { using 124-item high school } \\
\text { FFQ (1960-1980) }\end{array}$ \\
\hline
\end{tabular}
Adjustment variables

Age, smoking, race, parity and age

at first birth, height, BMl, weight,

family history of breast cancer, history of benign breast disease, oral contraceptive use, adult alcohol intake, physical activity, energy intake, hormone use and menopausal status, age at menopause.

\begin{tabular}{|c|c|c|c|c|c|}
\hline $\begin{array}{l}\text { Mourouti et al., } \\
2016 \text { [16] }\end{array}$ & Greece & Case-control & $\begin{array}{l}250 \text { cases/ } \\
250 \text { controls }\end{array}$ & $\begin{array}{l}56 \pm \\
12\end{array}$ & $\begin{array}{l}\text { FFQ (86 items, last year } \\
\text { to diagnosis) }\end{array}$ \\
\hline $\begin{array}{l}\text { Tajaddini et al., } \\
2015 \text { [18] }\end{array}$ & Iran & Case-control & $\begin{array}{l}306 \text { cases/ } \\
309 \text { controls }\end{array}$ & $25-65$ & $\begin{array}{l}\text { FFQ(136 items, a previo } \\
\text { year before diagnosis fo } \\
\text { or before interview for }\end{array}$ \\
\hline $\begin{array}{l}\text { Yun et al., } \\
2010 \text { [17] }\end{array}$ & Korea & Case-control & $\begin{array}{l}362 \text { cases/ } \\
362 \text { controls }\end{array}$ & $30-65$ & $\begin{array}{l}\text { quantitative food frequ } \\
\text { questionnaire (FFQ) wit } \\
121 \text { items }\end{array}$ \\
\hline $\begin{array}{l}\text { Egeberg et al., } \\
2009 \text { [23] }\end{array}$ & Denmark & $\begin{array}{l}\text { Danish Diet, } \\
\text { Cancer and } \\
\text { Health cohort } \\
\text { study (9.6) }\end{array}$ & $\begin{array}{l}25,278 \text { (978 } \\
\text { cases) }\end{array}$ & $50-64$ & $\begin{array}{l}\mathrm{FFQ}(192 \text { items, at } \\
\text { baseline 1993-1997) }\end{array}$ \\
\hline $\begin{array}{l}\text { Sonestedt et al., } \\
2008 \text { [19] }\end{array}$ & Sweden & $\begin{array}{l}\text { Malmo Diet } \\
\text { and Cancer } \\
\text { cohort(10.3) }\end{array}$ & $\begin{array}{l}15,773(544 \\
\text { cases) }\end{array}$ & $46-75$ & $\begin{array}{l}\text { a } 168 \text {-items dietary } \\
\text { questionnaire }\end{array}$ \\
\hline $\begin{array}{l}\text { Adzersen et al., } \\
2003 \text { [20] }\end{array}$ & Germany & Case-control & $\begin{array}{l}310 \text { cases/ } \\
353 \text { controls }\end{array}$ & $25-75$ & $\begin{array}{l}\text { FFQ (161items, Hospital } \\
\text { interview) }\end{array}$ \\
\hline
\end{tabular}

Age, BMI, International Physical Activity Questionnaire, Smoking ever, Menopausal status, Family history of breast cancer, MedDietScore.

Age at diagnosis, menopause, total calorie, parity, and BMI.

BMI, alcohol drinking, multivitamin use, number of children, breast feeding, and dietary factors including soy protein, folate, vitamin $\mathrm{E}$, and fiber.

Parity (parous/nulliparous and number of births), age at first birth, education, duration of hormone replacement therapy use, use of hormone replacement therapy, intake of alcohol and BMI.

Season of data collection, diet interviewer, method version, age, total energy, weight, height, educational status, smoking habits, leisure time physical activity, hours of household activities, alcohol consumption, age at menopause, parity and current use of HRT.

Age, total energy without alcohol intake, age at menarche, age at first birth, age at menopause, mother/sister with breast cancer, current smoking, history of benign breast disease and/or operation, BMI, consumption of alcohol, current HRT or HRT during the past year.

\begin{tabular}{|c|c|c|c|c|c|}
\hline $\begin{array}{l}\text { Nicodemus et al.., } \\
2001 \text { [22] }\end{array}$ & $\begin{array}{l}\text { United } \\
\text { States }\end{array}$ & $\begin{array}{l}\text { Cohort lowa } \\
\text { Women's Health } \\
\text { Study(9) }\end{array}$ & $\begin{array}{l}29,119(977 \\
\text { cases) }\end{array}$ & 55-69 & $\begin{array}{l}\text { a standard FFQ and an } \\
\text { additional question that } \\
\text { asked for the type of breakfast } \\
\text { cereal usually eaten }\end{array}$ \\
\hline
\end{tabular}

Age, energy intake, estrogen use, personal history of benign breast disease, family history of breast cancer, mammography status, age at first live birth, number of live births, current weight, waist-to-hip ratio, vitamin use, educational attainment, vitamin $\mathrm{A}$ and refined grain intake.

\begin{tabular}{|c|c|c|c|c|c|}
\hline $\begin{array}{l}\text { Chatenoud et al., } \\
1998 \text { [21] }\end{array}$ & Italy & Case-control & $\begin{array}{l}3412 \text { cases/ } \\
7990 \text { controls }\end{array}$ & $<74$ & $\begin{array}{l}\text { FFQ(14-37items, during the } \\
2 \text { years before diagnosis for case } \\
\text { or before interview for controls) }\end{array}$ \\
\hline $\begin{array}{l}\text { Levi et al., } \\
1993[25]\end{array}$ & Switzerland & Case-control & $\begin{array}{l}107 \text { cases/ } \\
318 \text { controls }\end{array}$ & $30-75$ & $\begin{array}{l}\text { Hospital interview, FFQ } \\
\text { (50 foods, since 1990) }\end{array}$ \\
\hline $\begin{array}{l}\text { LaVecchia } \\
\text { et al., } 1987 \text { [24] }\end{array}$ & Italy & Case-control & $\begin{array}{l}1108 \text { cases/ } \\
1281 \text { controls }\end{array}$ & $25-74$ & $\begin{array}{l}\text { Frequency of consumption of } \\
\text { major food sources year before } \\
\text { interview of first symptoms } \\
(1979-1984)\end{array}$ \\
\hline
\end{tabular}

Age, sex, education, smoking habits, alcohol intake and BMI.

Age, sex, education, BMI, physical activity, energy, parity.

Age, sex, education, green vegetables, fresh fruit, 7 reproductive variables, history of benign breast cancer for patient, mother, and sisters. 
Table 2 The type and dose of whole grain intake and the relative risk of breast cancer in the included studies

\begin{tabular}{|c|c|c|c|}
\hline Study & Type of whole grain intake & $\begin{array}{l}\text { Dose of whole grain } \\
\text { intake }(\mathrm{g} / \mathrm{d})\end{array}$ & Relative Risk(95\%Cl) \\
\hline Farvid et al., 2016 [15] & whole grain foods & $\begin{array}{l}\text { Q1: 5.6; Q2: 14; Q3: } \\
\text { 19.6; Q4: 28; Q5: } 42\end{array}$ & $\begin{array}{l}\text { Q1: 1; Q2: } 0.93 \text { (0.83-1.03); Q3: } 0.87 \\
\text { (0.77-0.97); Q4: } 0.91(0.81-1.02) ; \\
\text { Q5: } 0.91(0.81-1.03)\end{array}$ \\
\hline Mourouti et al., 2016 [16] & $\begin{array}{l}\text { whole grain foods (including whole } \\
\text { grain bread, whole grain cereals, } \\
\text { oatmeal, whole wheat pasta, } \\
\text { brown or wild rice) }\end{array}$ & No reported & $\begin{array}{l}\text { Never/rarely: } 1 ; 1-6 \text { times/week: } \\
0.68(0.41,1.09) ;>7 \text { times/week:0.49 } \\
(0.29,0.82)\end{array}$ \\
\hline Tajaddini et al., 2015 [18] & $\begin{array}{l}\text { whole-wheat bread (Sangak, Taftoon, } \\
\text { Barbari, barley, corn flakes and sprouts) }\end{array}$ & $<1.0 ; 1.0-23.0 ;>23.0$ & $\begin{array}{l}<1.0 \mathrm{~g} / \mathrm{d}: 1 ; 1.0-23.0 \mathrm{~g} / \mathrm{d}: \\
1.39(0.68-2.83) ;>23.0 \mathrm{~g} / \mathrm{d}: \\
0.61(0.37-0.99)\end{array}$ \\
\hline Yun et al., 2010 [17] & mixed brown rice & $0 ; 100 ; 350$ & $\begin{array}{l}0 \text { g/d:1.0; } 100 \text { g/d: } 0.90(0.47,1.71) \\
350 \text { g/d: } 0.42(0.20,0.87) \\
\text { Per } 100 \text { g/d: } 0.76(0.61,0.95)\end{array}$ \\
\hline Egeberg et al., 2009 [23] & $\begin{array}{l}\text { whole grain products (rye bread, } \\
\text { whole grain bread and oatmeal) }\end{array}$ & $\begin{array}{l}\leq 72 ; 72 \text { to } \leq 112 ; 112 \\
\text { to } \leq 163 ;>163\end{array}$ & $\begin{array}{l}\leq 72 \mathrm{~g} / \mathrm{d}: 1 ; 72 \text { to } \leq 112 \mathrm{~g} / \mathrm{d}: \\
0.98(0.82-1.17) ; \\
112 \text { to } \leq 163 \mathrm{~g} / \mathrm{d}: 1.00(0.85-1.19) ;> \\
163 \mathrm{~g} / \mathrm{d}: 1.03(0.85-1.24) \\
\text { Per each additional } 50 \mathrm{~g} / \text { day: } \\
1.01(0.96-1.07)\end{array}$ \\
\hline Sonestedt et al.,2008 [19] & $\begin{array}{l}\text { high-fibre bread ( } \geq 6 \% \text { of fibre for } \\
\text { soft bread, } \geq 10 \% \text { for crisp bread } \\
\text { and } \geq 10 \% \text { for biscuits and rusks) }\end{array}$ & $\begin{array}{l}\text { Q1: 0; Q2:9; Q3:19; Q4: } \\
\text { 34; Q5: } 65\end{array}$ & $\begin{array}{l}\text { Q1: 1; Q2: } 0.87(0.67-1.13) ; \text { Q3: } \\
\text { 0.74 (0.56-0.97); Q4: } 0.82(0.63-1.07) ; \\
\text { Q5: } 0.75(0.57-0.98)\end{array}$ \\
\hline Adzersen et al., 2003 [20] & $\begin{array}{l}\text { the whole-grain category all } \\
\text { whole-grain bread and rice, rolled } \\
\text { oats, muesli, and cornflakes. }\end{array}$ & $\begin{array}{l}\text { Q1: < 18.3; Q2:18.3 } \leq 32.6 \\
\text { Q3: } 32.6 \leq 45.5 ; Q 4:>45.5\end{array}$ & $\begin{array}{l}\text { Q1: 1; Q2: } 0.96(0.61,1.52) ; \text { Q3:0.76 } \\
(0.47-1.24) ; \mathrm{Q} 4: 0.57(0.34-0.95)\end{array}$ \\
\hline Nicodemus et al., 2001 [22] & whole grains & $\begin{array}{l}\text { Q1:0-3.5; Q2: 4-7; Q3: } \\
\text { 7.5-10.5; Q4:11-18.5; } \\
\text { Q5:19-108.5 (servings/week) }\end{array}$ & $\begin{array}{l}\text { Q1: 1; Q2: } 0.95(0.76-1.2) ; \text { Q3: } \\
\text { 1.04 (0.84-1.3); Q4: } 1.19(0.96-1.5) ; \\
\text { Q5: } 1.21(0.96-1.5)\end{array}$ \\
\hline Chatenoud et al., 1998 [21] & $\begin{array}{l}\text { whole grain food (essentially } \\
\text { bread or pasta) }\end{array}$ & No reported & $\begin{array}{l}\text { Low (no or rare consumption): } 1 \\
\text { Intermediate ( } 1-3 \text { days/week): } \\
0.9(0.8-1.0) ; \text { High (>3 days/week): } \\
0.9(0.8-1.0)\end{array}$ \\
\hline Levi et al., 1993 [25] & whole-grain bread and pasta & No reported & $\begin{array}{l}\text { Low: } 1 \text {; Intermediate: } 0.77(0.41-1.44) \text {; } \\
\text { High: } 0.63(0.35-1.15)\end{array}$ \\
\hline LaVecchia et al., 1987 [24] & whole-grain bread or pasta & No reported & $\begin{array}{l}\text { Never: } 1 \text {; Occasionally: } 0.75(0.57-0.96) ; \\
\text { Frequently: } 0.90(0.69-1.17)\end{array}$ \\
\hline
\end{tabular}

$\mathrm{Q}=$ quintiles or quartiles

According to the NOS criteria, the quality scores of the included studies ranged from 6 to 9 (Tables 3 and 4). Nine studies were considered as high-quality and two as low-quality studies. Most case-control studies had exposure assessment and selection biases and did not report the non-response rates.

\section{Associations between whole grain intake and the risk of breast cancer}

The RRs of breast cancer risk comparing the highest versus the lowest levels of whole grain intake varied from 0.42 to 1.21 across the studies (Fig. 2). Five studies showed a significant inverse association [16-20], one study reported a marginally significant association [21], whereas no association was found in the remaining five studies [15, 22-25]. When the results were combined by using random-effects method, a significant inverse association was observed
Table 3 Assessment of study quality included in the meta-analysis by Newcastle Ottawa Scale (NOS) for case-control studies

\begin{tabular}{|c|c|c|c|c|c|c|c|c|c|c|}
\hline \multirow[t]{2}{*}{ Source } & \multicolumn{4}{|c|}{ Selection } & \multicolumn{2}{|c|}{ Comparability } & \multicolumn{3}{|c|}{ Exposure } & \multirow[t]{2}{*}{ Total scores } \\
\hline & 1 & 2 & 3 & 4 & $5 A$ & $5 B$ & 6 & 7 & 8 & \\
\hline Mourouti et al. & * & * & * & * & * & * & * & * & - & 8 \\
\hline Tajaddini et al. & * & * & - & * & * & * & * & * & - & 7 \\
\hline Yun et al & $*$ & * & - & - & $*$ & $*$ & $*$ & $*$ & - & 6 \\
\hline Adzersen et al. & * & * & - & * & * & * & - & * & - & 6 \\
\hline Chatenoud et al. & * & * & - & * & $*$ & $*$ & - & * & * & 7 \\
\hline Levi et al. & * & - & - & * & * & * & $*$ & * & $*$ & 7 \\
\hline LaVecchia et al & * & * & - & * & * & * & * & * & * & 8 \\
\hline
\end{tabular}

1 Is the case definition adequate? 2 Representativeness of the cases. 3 Selection of controls. 4 Definition of controls. 5 Comparability of cases and controls on the basis of the design or analysis. 6 Ascertainment of exposure. 7 Same method of ascertainment for cases and controls. 8 Non-response rate

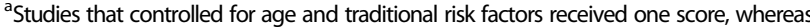
studies that controlled for other important confounders received an additional score 
Table 4 Assessment of study quality included in the meta-analysis by Newcastle Ottawa Scale (NOS) for cohort studies

\begin{tabular}{|c|c|c|c|c|c|c|c|c|c|c|}
\hline \multirow[t]{2}{*}{ Source } & \multicolumn{4}{|c|}{ Selection } & \multicolumn{2}{|c|}{ Comparability $^{a}$} & \multicolumn{3}{|c|}{ Outcome } & \multirow[t]{2}{*}{ Total scores } \\
\hline & 1 & 2 & 3 & $\overline{4}$ & $\overline{5 A}$ & $5 B$ & 6 & $7^{b}$ & $\overline{8^{c}}$ & \\
\hline Farvid et al & - & * & $*$ & $*$ & * & $*$ & * & * & * & 8 \\
\hline Egeberg et al. & * & * & - & $*$ & * & * & * & * & - & 7 \\
\hline Sonestedt et al & * & * & $*$ & $*$ & * & * & * & * & * & 9 \\
\hline Nicodemus et al. & * & * & $*$ & $*$ & * & * & * & * & - & 8 \\
\hline
\end{tabular}

1 Representativeness of the exposed cohort. 2 Selection of the non-exposed cohort 3 Ascertainment of exposure for cohort studies. 4 Demonstration that outcome of interest was not present at start of study for cohort studies. 5 Comparability of cohorts on the basis of the design or analysis. 6 Assessment of outcome. 7 Was follow-up long enough for outcomes to occur. 8 Adequacy of follow up of cohorts ${ }^{a}$ Studies that controlled for age and traditional risk factors received one score, whereas studies that controlled for other important confounders received an additional score

${ }^{\mathrm{b}}$ study with follow-up time $>2$ years was assigned one score

cstudy with follow-up rate $>70 \%$ was assigned one score

(RR: $0.84,95 \%$ CI: 0.74 to $0.96, p=0.009$ ), with significant heterogeneity $\left(I^{2}=63.8 \%, p=0.002\right)$.

Whole grain intake was classified in different ways in the included studies, quintiles in three studies $[15,19,22]$, quartiles in two studies [20,23], and tertiles in the other six studies. We combined quintile 2 and 3 into intermediate intake level, quintile 4 and 5 and quartile 3 and 4 into high level, to further quantify the associations of different intake levels of whole grain intake with breast cancer risk.
A significant inverse association was found for both the intermediate intake level (RR: 0.90, 95\%CI: 0.86, 0.95; $p<0.001)$ and the high intake level of whole grains (RR: $0.85,95 \%$ CI: 0.76, 0.95, $p=0.004$ ). No significant heterogeneity was observed for the intermediate intake level $\left(I^{2}=0.0 \%, p=0.525\right)$, whereas significant heterogeneity was found for the high intake level $\left(I^{2}=66.6 \%, p=0.001\right)$ (Fig. 3). Six studies reported the intake of whole grain as a continuous variable $(\mathrm{g} / \mathrm{d})$. The pooled analysis showed that an average $50 \mathrm{~g} / \mathrm{d}$ intake of whole grain was significantly associated with a $17 \%$ reduced risk of breast cancer with significant heterogeneity (RR: 0.83 , 95\% CI: 0.73, 0.93; $I^{2}=70.5 \%, p=0.005$ ) (Fig. 4). To explore the association between the dose of whole grain intake and breast cancer risk, we further performed a meta-regression analysis and found an inverse association between the dose of whole grain and breast cancer risk (Fig. 5).

\section{Stratified and sensitivity analyses}

Stratified analysis by study design found a significant inverse association between whole grain intake and breast cancer risk in the seven case-control studies (RR:0.69, 95\% CI: 0.56 to $0.87, p=0.001 ; I^{2}=58.2 \%, p$ for heterogeneity $=0.026$ ), but no association in the four cohort studies (RR: $0.96,95 \%$ CI: 0.82 to $1.14, p=0.69 ; I^{2}=66.7 \%, \mathrm{p}$ for heterogeneity $=0.029$ ). In addition, a significant association was observed in studies with sample size $\leq 2300$ (RR: $0.55,95 \%$ CI: 0.43 to 0.70 ,

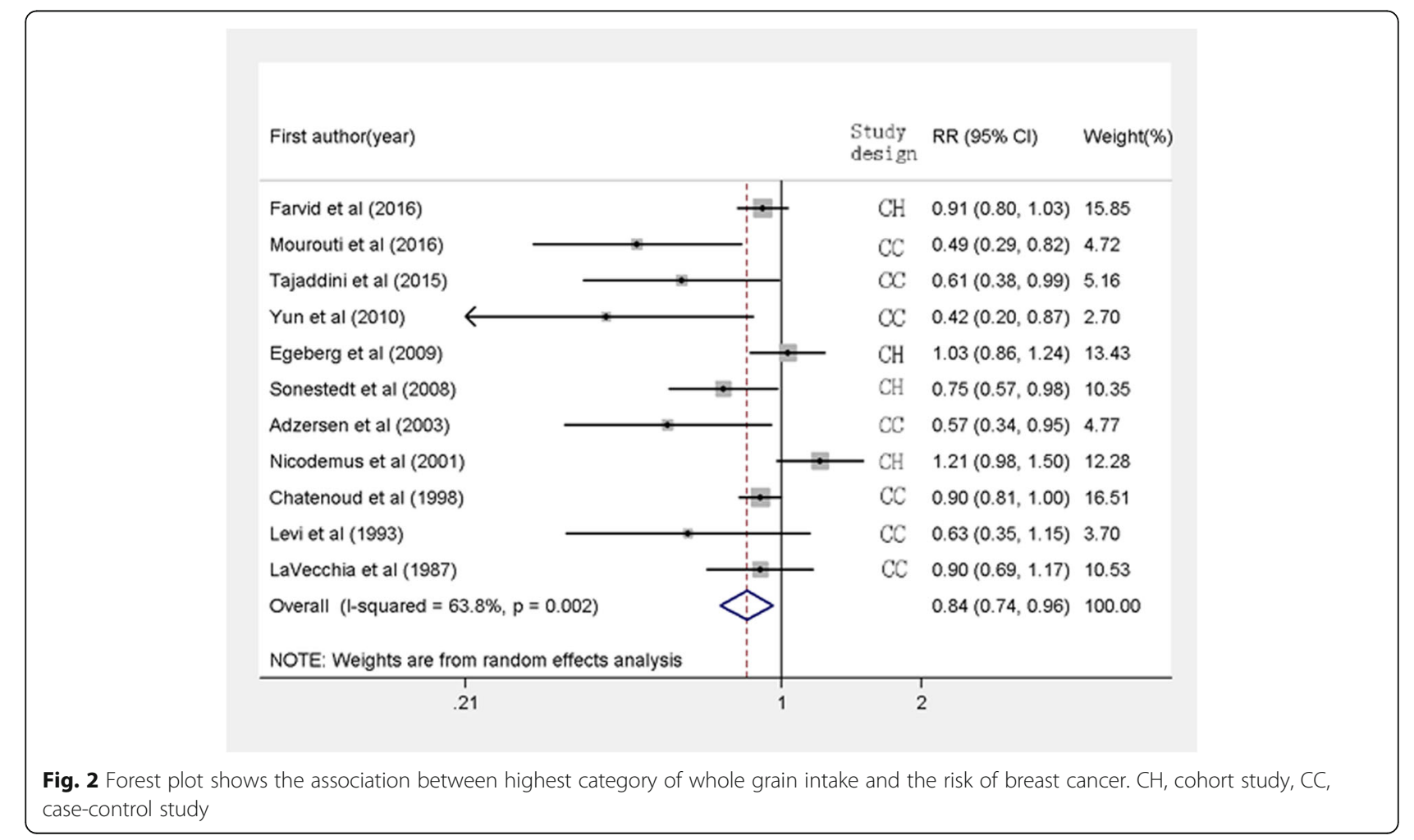




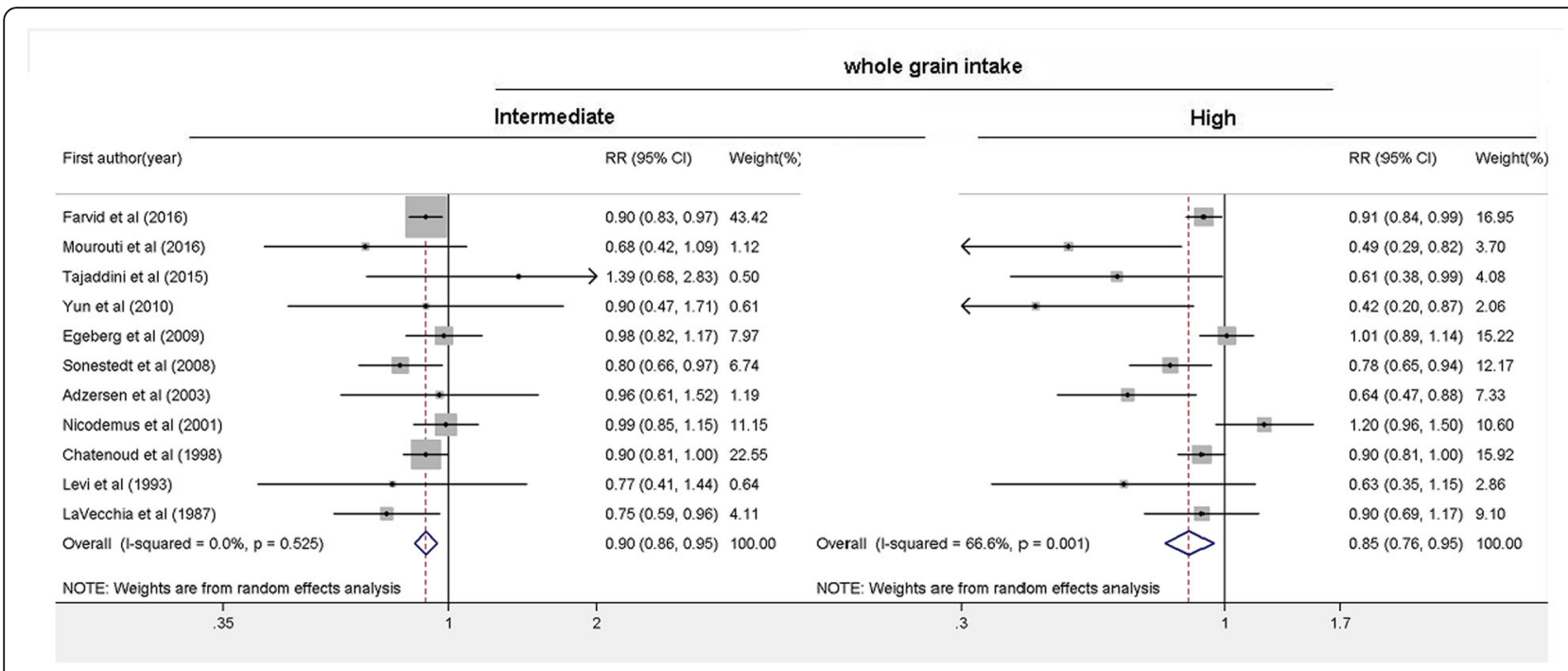

Fig. 3 Forest plot shows the association between high and intermediate levels of whole grain intake and the risk of breast cancer

$p<0.001)$, those with the number of adjusted variables $\leq 7$ (RR: 0.80, 95\% CI: 0.64 to $0.99, p=0.04$ ), studies published before 2008 (RR: 0.75 , 95\% CI: 0.58 to $0.97, p=0.03$ ), or studies with quality score $\leq 7$ (RR: $0.77,95 \% \mathrm{CI}: 0.63$ to $0.96, p=0.019)$. To explore whether these associations were statistically different between the subgroups, we further performed meta-regression analyses and found the association was statistically different between the subgroups of sample size $(p<0.05)$ but was not significant between other subgroups (Additional file 2: Figure S1). Significant heterogeneity was observed in different subgroups based on publication year, numbers of adjusted variables, and quality score. However, no significant heterogeneity was observed in subgroups based on sample size, suggesting sample size may be a possible source of heterogeneity across the studies (Table 5).

Sensitivity analyses were also conducted to assess the influence of each individual study on the summary

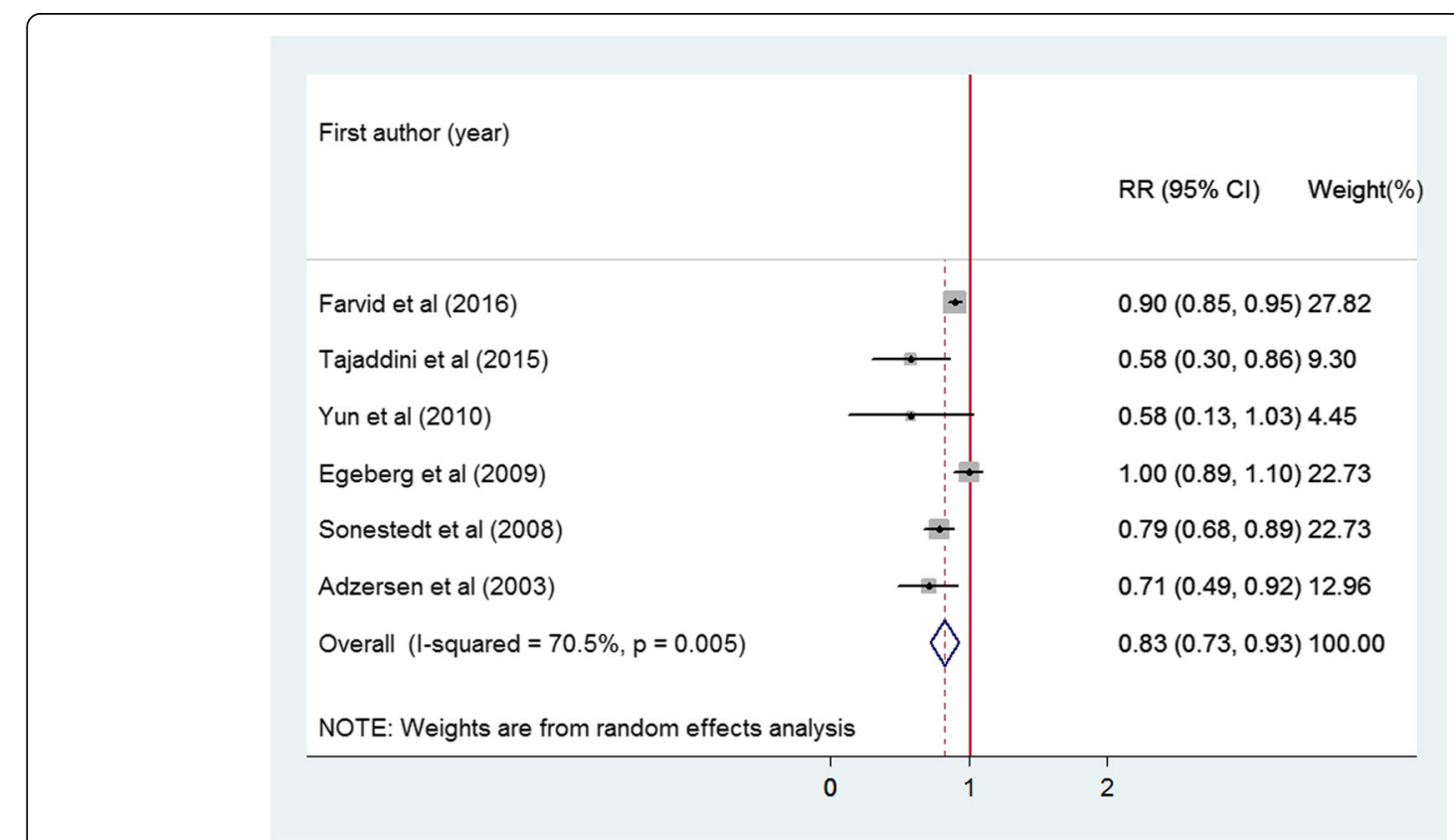

Fig. 4 Forest plot shows the association between whole grain intake (per $50 \mathrm{~g} /$ day) as a continuous variable and the risk of breast cancer 


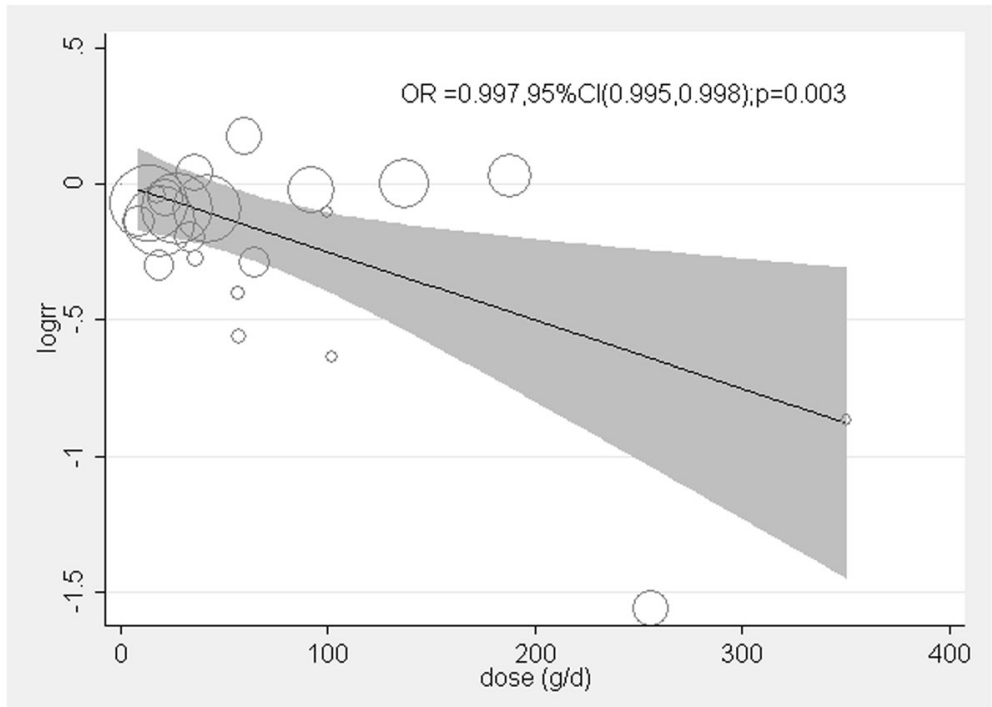

Fig. 5 Meta regression analysis of the association between the dose of whole grain intake and the risk of breast cancer

estimates by eliminating one study at a time. The results suggest that the estimates were robust, with the summary RRs ranging from 0.86 to 0.90 and all $p$ values $<0.05$ (Additional file 3: Figure S2).

\section{Publication bias}

Although the funnel plot was slightly asymmetric, after using the trim-and-fill method, visual inspection of the Begg funnel plot did not identify substantial asymmetry (Additional file 4: Figure S3). In addition, the Begg rank correlation test and Egger linear regression test showed no evidence of publication bias (Begg test, $p=0.300$; Egger test, $p=0.309)$.

\section{Discussion}

To the best of our knowledge, this is the first meta-analysis of observational studies to quantitatively summarize the evidence of the association between whole grain intake and the risk of breast cancer. The results suggest that intermediate and high intake levels of whole grain were associated with a modest reduction of breast cancer risk. The meta-regression analysis found

Table 5 Subgroup analyses for the association between whole grain intake and breast cancer risk

\begin{tabular}{|c|c|c|c|c|c|c|}
\hline Subgroups & No. of studies & RR $(95 \% \mathrm{Cl})$ & $P$ & Heterogeneity $x^{2}$ & $P^{2}(\%)$ & $P$ for heterogeneity \\
\hline Overall & 11 & $0.84(0.74,0.96)$ & 0.009 & 27.6 & 63.8 & 0.002 \\
\hline \multicolumn{7}{|l|}{ Study design } \\
\hline Cohort study & 4 & $0.96(0.82,1.14)$ & 0.69 & 9.0 & 66.7 & 0.029 \\
\hline Case-control study & 7 & $0.69(0.56,0.87)$ & 0.001 & 14.3 & 58.2 & 0.026 \\
\hline \multicolumn{7}{|l|}{ Sample size } \\
\hline$\leq 2300$, below median & 5 & $0.55(0.43,0.70)$ & $<0.001$ & 1.1 & 0.0 & 0.893 \\
\hline$>2300$, above median & 6 & $0.94(0.85,1.04)$ & 0.25 & 9.9 & 49.8 & 0.077 \\
\hline \multicolumn{7}{|l|}{ Publication year } \\
\hline After 2008 & 6 & $0.87(0.74,1.03)$ & 0.12 & 13.4 & 62.9 & 0.019 \\
\hline Before 2008 & 5 & $0.75(0.58,0.97)$ & 0.032 & 14.1 & 71.6 & 0.007 \\
\hline \multicolumn{7}{|c|}{ Number of adjustment for covariates } \\
\hline$\leq 7$ & 5 & $0.80(0.64,0.99)$ & 0.04 & 11.1 & 64.2 & 0.025 \\
\hline$>7$ & 6 & $0.84(0.69,1.04)$ & 0.11 & 16.3 & 69.4 & 0.006 \\
\hline \multicolumn{7}{|l|}{ Study quality score } \\
\hline$\leq 7$ & 6 & $0.77(0.63,0.96)$ & 0.019 & 13.0 & 61.6 & 0.023 \\
\hline$>7$ & 5 & $0.87(0.71,1.07)$ & 0.19 & 14.3 & 72.0 & 0.006 \\
\hline
\end{tabular}


an inverse association between the dose of whole grain intake and the risk of breast cancer. In addition, stratified analyses found this inverse association was significant in case-control studies, but not in cohort studies.

In 1987, La Vecchia et al. [24] first reported that the intake of whole grain bread was inversely associated with the risk of breast cancer in a case-control study conducted in Italy. Subsequently, another case-control study published in 1993 by Levi et al. [25] did not find a significant association. In 1998, Jacobs et al. [14] conducted a meta-analysis of 40 case-controls studies including 20 cancer sites and found that whole grain consumption was protective against different types of cancer, such as colon cancer, gastric cancer, and pancreatic cancer. Because only the above two case-control studies were included in that review and meta-analysis, no significant association was observed for breast cancer. Since then, nine observational studies have published with inconsistent results reported. In the present meta-analysis including 11 observational studies, we found that whole grain intake was significantly inversely associated with breast cancer risk.

Several mechanisms have been proposed to explain the reduced risk of breast cancer with whole grain intake. Whole grains contain various micronutrients and are rich in non-nutrients that are lost in the refining process but may be potentially beneficial in preventing cancer $[51,52]$. First, whole grains may reduce the postprandial glucose and insulin responses leading to better glycemic control [53]. Higher serum insulin levels have been found to be associated with an increased breast cancer risk in several epidemiological studies [54, 55]. Therefore, insulin and glycemic control could be a potential pathway through which whole grains may reduce breast cancer risk. Whole grain has also been found to be associated with reduced levels of inflammatory markers (plasminogen activator inhibitor-1, C-reactive protein) and liver enzymes (gamm-glutamyltranspeptidse, aspartate aminotransferase) [56], and higher levels of these markers and enzymes were associated with an increased risk of cancer [57]. Second, whole grains are a rich source of dietary fiber. A recent meta-analysis of 16 prospective studies found that dietary fiber intake was inversely associated with breast cancer risk [13]. High fiber foods are known to have potential anticarcinogenic properties, for instance, reducing N-nitroso compounds, enhancing immunity, and particularly producing various anti-inflammatory cytokines, which may be involved in the initiation and progression of breast cancer [58]. Dietary fibre can reduce cancer risk through removing damaged cells from the digestive tract [59], increasing stool bulk, diluting carcinogens, decreasing transit time, altering the gut microbiota [60-62], and binding oestrogens in the colon and increasing the faecal excretion of oestrogens, leading to lower oestrogen concentrations [63]. In addition, dietary fiber can bind to or dilute bile acids to reduce cell proliferation and the chance of mutations [64]. Third, whole grains are rich in antioxidants, including vitamins (vitamin $\mathrm{C}$ and $\mathrm{E}$ and $\beta$-carotene) and trace minerals (selenium, zinc, copper, and manganese), which are components of enzymes with antioxidant functions. Vitamin E inhibits cancer through preventing carcinogen formation and blocking carcinogen-cell interactions [65]. These vitamins and trace minerals have been found to be inversely associated with breast cancer risk [56]. Finally, whole grains are a significant source of some essential non-nutrients, such as phytoestrogens, phenolic acids, and lignans. These natural compounds play important protective roles against cancer through their antioxidant properties and abilities to inhibit cell proliferation and angiogenesis and to induce cell apoptosis, as well as through modulating hormonal pathways [66]. Although these mechanisms are biologically plausible, it is difficult to determine the specific bioactive components of whole grains which contribute to breast cancer risk reduction in epidemiologic research. Further experimental studies are needed to confirm the underlying mechanisms through which whole grains or the bioactive components reduce breast cancer risk.

Heterogeneity poses an important challenge in conducting and interpreting the results of meta-analyses [67]. Various factors may contribute to heterogeneity. As the overall results of our meta-analysis revealed significant heterogeneity across the included studies, subgroup analyses were conducted to find the potential sources. The results showed significant heterogeneity in subgroups stratified by study design, publication year, the number of adjusted covariates, and study quality score (all $p<0.05$ ). However, the stratified analyses by sample size found that heterogeneity was no longer significant in the two subgroups $\left(I^{2}=0 \%\right.$ and $49.8 \%$, both $\left.p>0.05\right)$, suggesting that sample size might be a potential source of heterogeneity. In addition, the association was only significant in case-control studies, in studies with sample size $\leq 2300$, published before 2008, or studies with the number of adjusted covariates $\leq 7$ or quality score $\leq 7$, but not significant in cohort studies, in studies with sample size $>2300$, published after 2008, or studies with the number of adjusted covariates $>7$ or with quality score $>7$. Approximately two thirds of the studies were case-control studies with inadequate adjustment of potential confounders and comparatively low quality. Given that the possible recall bias and selection bias in case-control studies, and the limited number of only four cohort studies, more large-scale prospective cohort studies with full adjustment for potential confounding factors are urgently needed to confirm the inverse association observed in the current meta-analysis.

Our meta-analysis has several limitations. First, it included seven case-control studies and four cohort studies. 
As indicated above, case-control studies are likely susceptible to recall and selection bias. Second, the quality of the included studies was moderate and the inverse association was only observed in low quality studies (NOS $\leq 7, n=6$ ) in the subgroup analysis by quality score. Third, the intake levels of whole grain were reported in six included studies. However, a dose-response meta-analysis could not be conducted due to incomplete data and the inconsistencies in the measurement units of whole grain intake and different assessment methods. We did perform a meta-regression analysis to explore the association between dose of whole grain intake and breast cancer risk and found an inverse association. In addition, differences in the definitions of whole grain and in the categories of whole grain foods among studies might also be another possible source of heterogeneity. Fourth, the $95 \% \mathrm{CI}$ was not reported in one study [25] and was extracted from a previous meta-analysis [14] which may result in inaccurate estimates. Finally, although most included studies adjusted for major potential confounders, other unmeasured and uncontrolled confounders, such as coffee [68] and green tea consumption [69], may potentially affect the validity of the results to some extent.

\section{Conclusions}

Dietary intake of whole grains was inversely associated with breast cancer risk in the current meta-analysis, and the inverse association was only observed in case-control but not cohort studies. Considering a limited number of case-control studies, the potential biases of case-control studies, and that sample size may be a potential source of heterogeneity, large well-designed prospective cohort studies need to be conducted. Future studies should further elucidate the dose-response relationship and assess the associations of whole grain and whole wheat with breast cancer.

\section{Additional files}

Additional file 1: PRISMA 2009 Checklist. (DOC 64 kb)

Additional file 2: Figure S1. Meta regression analysis of the association between the publication year $(A, p=0.43)$, the sample size $(B, p=0.04)$, the number of adjustment covariates $(C, p=0.36)$, and the study quality score ( $D, p=0.32)$ and the risk of breast cancer. (TIF $62 \mathrm{~kb}$ )

Additional file 3: Figure S2. Sensitivity analyses of the association between whole grain intake and the risk of breast cancer with one study omitted at a time. (TIF $7 \mathrm{~kb}$ )

Additional file 4: Figure S3. Publication bias assessed by funnel plot of the association between whole grain intake and the risk of breast cancer in the meta-analysis. (TIF $10 \mathrm{~kb}$ )

\section{Abbreviations}

Cl: Confidence interval; HRs: Hazard ratios; IDRs: Incidence density ratios; MESH: Medical subject headings; NOS: Newcastle Ottawa Scale; ORs: Odds ratios; RR: Relative risk; SEs: Standard errors

\section{Funding}

This study was supported by grants from the National Natural Science Foundation of China (81402672) and Hong Kong Research Grants Council General Research Fund (14113414).

\section{Availability of data and materials}

The tables and figures supporting the conclusions of this article are included within the article.

\section{Authors' contributions}

YX, XS and RMT contributed to the conception and design of the study. YX, SW and SH conducted the literature search and data extraction. $Y X$ and $Z \mathrm{~L}$ performed the statistical analyses. YX, YK, SW, SH, ZL, SL, EY, XL, SW, JK and XS drafted the manuscript. RMT and GAC supervised the study. All authors gave final approval.

Ethics approval and consent to participate

Not applicable.

\section{Consent for publication}

Not applicable.

\section{Competing interests}

The authors declare that they have no competing interests.

\section{Publisher's Note}

Springer Nature remains neutral with regard to jurisdictional claims in published maps and institutional affiliations.

\section{Author details}

'Shenzhen Key Laboratory of Molecular Epidemiology, Shenzhen Center for Disease Control and Prevention, Shenzhen, China. ${ }^{2}$ School of Public Health and Primary Care, Faculty of Medicine, School of Public Health, Prince of Wales Hospital, The Chinese University of Hong Kong, Room 508, Shatin, New Territories, Hong Kong, China. ${ }^{3}$ Alvin J. Siteman Cancer Center and Department of Surgery, Washington University School of Medicine, St. Louis, USA. ${ }^{4}$ Channing Division of Network Medicine, Brigham and Women's Hospital, Harvard Medical School, 181 Longwood Avenue, Boston, MA 02115 USA. ${ }^{5}$ Department of Epidemiology, Harvard T.H. Chan School of Public Health, Boston, USA

Received: 6 November 2017 Accepted: 4 April 2018

Published online: 21 September 2018

\section{References}

1. Jemal A, Siegel R, Xu J, Ward E. Cancer statistics, 2010. CA Cancer J Clin. 2010;60(5):277-300.

2. Thomson CA. Diet and breast cancer: understanding risks and benefits. Nutr Clin Pract. 2012;27(5):636-50.

3. Slavin $\mathrm{J}$, Jacobs $D$, Marquart $L$, Wiemer $K$. The role of whole grains in disease prevention. J Am Diet Assoc. 2001;101:780-5.

4. Aune D, Norat T, Romundstad P, Vatten LJ. Whole grain and refined grain consumption and the risk of type 2 diabetes: a systematic review and dose-response meta-analysis of cohort studies. Eur J Epidemiol. 2013;28(11):845-58.

5. Ye EQ, Chacko SA, Chou EL, Kugizaki M, Liu S. Greater whole-grain intake is associated with lower risk of type 2 diabetes, cardiovascular disease, and weight gain. J Nutr. 2012;142(7):1304-13.

6. de Munter JS, Hu FB, Spiegelman D, Franz M, van Dam RM. Whole grain, bran, and germ intake and risk of type 2 diabetes: a prospective cohort study and systematic review. PLoS Med. 2007;4(8):e261.

7. Flight I, Clifton P. Cereal grains and legumes in the prevention of coronary heart disease and stroke: a review of the literature. Eur J Clin Nutr. 2006; 60(10):1145-59.

8. Aune D, Keum N, Giovannucci E, Fadnes LT, Boffetta P, Greenwood DC, Tonstad S, Vatten LJ, Riboli E, Norat T. Whole grain consumption and risk of cardiovascular disease, cancer, and all cause and cause specific mortality: systematic review and dose-response meta-analysis of prospective studies. BMJ (Clinical research ed). 2016;i2716:353. 
9. Zong G, Gao A, Hu FB, Sun Q. Whole grain intake and mortality from all causes, cardiovascular disease, and Cancer: a Meta-analysis of prospective cohort studies. Circulation. 2016;133(24):2370-80.

10. Ma X, Tang WG, Yang Y, Zhang QL, Zheng JL, Xiang YB. Association between whole grain intake and all-cause mortality: a meta-analysis of cohort studies. Oncotarget. 2016;7(38):61996-62005.

11. La Vecchia C, Chatenoud L, Negri E, Franceschi S. Session: whole cereal grains, fibre and human cancer wholegrain cereals and cancer in Italy. Proc Nutr Soc. 2003;62(1):45-9.

12. Aune D, Chan DS, Lau R, Vieira R, Greenwood DC, Kampman E, Norat T. Dietary fibre, whole grains, and risk of colorectal cancer: systematic review and dose-response meta-analysis of prospective studies. BMJ (Clinical research ed). 2011;343:d6617.

13. Aune D, Chan DS, Greenwood DC, Vieira AR, Rosenblatt DA, Vieira R, Norat T. Dietary fiber and breast cancer risk: a systematic review and meta-analysis of prospective studies. Ann Oncol. 2012;23(6):1394-402.

14. Jacobs DR Jr, Marquart L, Slavin J, Kushi LH. Whole-grain intake and cancer: an expanded review and meta-analysis. Nutr Cancer. 1998;30(2):85-96.

15. Farvid MS, Cho E, Eliassen AH, Chen WY, Willett WC. Lifetime grain consumption and breast cancer risk. Breast Cancer Res Treat. 2016;159(2):335-45.

16. Mourouti N, Kontogianni MD, Papavagelis C, Psaltopoulou T, Kapetanstrataki MG, Plytzanopoulou P, Vassilakou T, Malamos N, Linos A, Panagiotakos DB. Whole grain consumption and breast Cancer: a case-control study in women. J Am Coll Nutr. 2016;35(2):143-9.

17. Yun SH, Kim K, Nam SJ, Kong G, Kim MK. The association of carbohydrate intake, glycemic load, glycemic index, and selected rice foods with breast cancer risk: a case-control study in South Korea. Asia Pac J Clin Nutr. 2010;19(3):383-92.

18. Tajaddini A, Pourzand A, Sanaat Z, Pirouzpanah S. Dietary resistant starch contained foods and breast cancer risk: a case-control study in northwest of Iran. Asian Pac J Cancer Prev. 2015;16(10):4185-92.

19. Sonestedt E, Borgquist S, Ericson U, Gullberg B, Landberg G, Olsson H, Wirfalt E. Plant foods and oestrogen receptor - and -defined breast cancer: observations from the Malmo diet and cancer cohort. Carcinogenesis. 2008;29(11):2203-9.

20. Adzersen K-H, Jess P, Freivogel KW, Gerhard I, Bastert G. Raw and cooked vegetables, fruits, selected micronutrients, and breast Cancer risk: a casecontrol study in Germany. Nutr Cancer. 2003;46(2):131-7.

21. Chatenoud L, Tavani A, La Vecchia C, Jacobs DR Jr, Negri E, Levi F, Franceschi S Whole grain food intake and cancer risk. Int J Cancer. 1998;77(1):24-8.

22. Nicodemus KK, Jacobs DR Jr, Folsom AR. Whole and refined grain intake and risk of incident postmenopausal breast cancer (United States). Cancer Causes Control. 2001;12(10):917-25.

23. Egeberg R, Olsen A, Loft S, Christensen J, Johnsen NF, Overvad K, Tjonneland A. Intake of whole grain products and risk of breast cancer by hormone receptor status and histology among postmenopausal women. Int J Cancer. 2009;124(3):745-50.

24. La Vecchia C, Decarli A, Franceschi S, Gentile A, Negri E, Parazzini F. Dietary factors and the risk of breast cancer. Nutr Cancer. 1987;10(4):205-14

25. Levi F, La Vecchia C, Gulie C, Negri E. Dietary factors and breast cancer risk in Vaud, Switzerland. Nutr Cancer. 1993;19(3):327-35.

26. Stroup DF, Berlin JA, Morton SC, Olkin I, Williamson GD, Rennie D, Moher D, Becker BJ, Sipe TA, Thacker SB. Meta-analysis of observational studies in epidemiology: a proposal for reporting. Meta-analysis of observational studies in epidemiology (MOOSE) group. JAMA. 2000;283(15):2008-12

27. La Moher D, Tetzlaff J, Altman DG. The PRISMA group: preferred reporting items for systematic reviews and Meta-analyses: the PRISMA statement. PLoS Med. 2009;6(7):e1000097.

28. Boffetta P, Thies F, Kris-Etherton P. Epidemiological studies of oats consumption and risk of cancer and overall mortality. Br J Nutr. 2014;112(Suppl 2):S14-8.

29. Potischman N, Swanson CA, Coates RJ, Gammon MD, Brogan DR, Curtin J, Brinton LA. Intake of food groups and associated micronutrients in relation to risk of early-stage breast cancer. Int J Cancer. 1999;82(3):315-21.

30. Bessaoud F, Daures JP, Gerber M. Dietary factors and breast cancer risk: a case control study among a population in southern France. Nutr Cancer. 2008;60(2):177-87.

31. Favero A, Parpinel M, Franceschi S. Diet and risk of breast cancer: major findings from an Italian case-control study. Biomed Pharmacother. 1998;52(3):109-15.

32. Van 't Veer P, Kolb CM, Verhoef P, Kok FJ, Schouten EG, Hermus RJ, Sturmans F. Dietary fiber, beta-carotene and breast cancer: results from a case-control study. Int J Cancer. 1990;45(5):825-8.
33. Ahmadnia Z, Joukar F, Hasavari F, Roushan ZA, Khalili M. Dietary patterns and risk of breast Cancer in women in Guilan Province, Iran. Asian Pac J Cancer Prev. 2016;17(4):2035-40.

34. Agurs-Collins T, Rosenberg L, Makambi K, Palmer JR, Adams-Campbell L. Dietary patterns and breast cancer risk in women participating in the black Women's health study. Am J Clin Nutr. 2009;90(3):621-8.

35. Link LB, Canchola AJ, Bernstein L, Clarke CA, Stram DO, Ursin G, Horn-Ross $\mathrm{PL}$. Dietary patterns and breast cancer risk in the California teachers study cohort. Am J Clin Nutr. 2013:98(6):1524-32.

36. Assi N, Moskal A, Slimani N, Viallon V, Chajes V, Freisling H, Monni S, Knueppel S, Forster J, Weiderpass E, et al. A treelet transform analysis to relate nutrient patterns to the risk of hormonal receptor-defined breast cancer in the European prospective investigation into cancer and nutrition (EPIC). Public Health Nutr. 2016;19(2):242-54.

37. Franceschi S, La Vecchia C, Russo A, Negri E, Favero A, Decarli A. Low-risk diet for breast cancer in Italy. Cancer Epidemiol Biomarkers Prev. 1997;6(11):875-9.

38. Terry P, Suzuki R, Hu FB, Wolk A. A prospective study of major dietary patterns and the risk of breast cancer. Cancer Epidemiol Biomarkers Prev. 2001:10(12):1281-5.

39. Franceschi S, Favero A, La Vecchia C, Negri E, Dal Maso L, Salvini S, Decarli A, Giacosa A. Influence of food groups and food diversity on breast cancer risk in Italy. Int J Cancer. 1995;63(6):785-9.

40. Kwan ML, Weltzien E, Kushi LH, Castillo A, Slattery ML, Caan BJ. Dietary patterns and breast cancer recurrence and survival among women with early-stage breast cancer. J Clin Oncol. 2009;27(6):919-26.

41. Freudenheim JL, Marshall JR, Vena JE, Laughlin R, Brasure JR, Swanson MK, Nemoto T, Graham S. Premenopausal breast cancer risk and intake of vegetables, fruits, and related nutrients. J Natl Cancer Inst. 1996;88(6):340-8.

42. Deschasaux M, Zelek L, Pouchieu C, His M, Hercberg S, Galan P, LatinoMartel P, Touvier M. Prospective association between dietary fiber intake and breast cancer risk. PLoS One. 2013;8(11):e79718.

43. Lei Q, Zheng $H$, Bi J, Wang X, Jiang T, Gao X, Tian F, Xu M, Wu C, Zhang L, et al. Whole grain intake reduces pancreatic cancer risk: a Meta-analysis of observational studies. Medicine. 2016;95(9):e2747.

44. Berkey CS, Willett WC, Tamimi RM, Rosner B, Frazier AL, Colditz GA. Vegetable protein and vegetable fat intakes in pre-adolescent and adolescent girls, and risk for benign breast disease in young women. Breast Cancer Res Treat. 2013;141(2):299-306.

45. Zhang R, Zhang X, Wu K, Wu H, Sun Q, Hu FB, Han J, Willett WC, Giovannucci EL. Rice consumption and cancer incidence in US men and women. Int J Cancer. 2016;138(3):555-64.

46. DerSimonian R, Laird N. Meta-analysis in clinical trials. Control Clin Trials. 1986;7(3):177-88

47. Riley RD, Higgins JP, Deeks JJ. Interpretation of random effects meta-analyses. BMJ. 2011;342:d549.

48. Higgins JP, Thompson SG, Deeks JJ, Altman DG. Measuring inconsistency in meta-analyses. BMJ. 2003:327(7414):557-60.

49. Egger M, Davey Smith G, Schneider M, Minder C. Bias in meta-analysis detected by a simple, graphical test. BMJ. 1997:315(7109):629-34.

50. Begg CB, Mazumdar M. Operating characteristics of a rank correlation test for publication bias. Biometrics. 1994;50(4):1088-101.

51. Slavin JL. Whole grains, refined grains and fortified refined grains: What's the difference? Asia Pac J Clin Nutr. 2000;9(Suppl 1):S23-7.

52. Gil A, Ortega RM, Maldonado J. Wholegrain cereals and bread: a duet of the Mediterranean diet for the prevention of chronic diseases. Public Health Nutr. 2011;14(12a):2316-22.

53. Chandalia M, Garg A, Lutjohann D, von Bergmann K, Grundy SM, Brinkley LJ. Beneficial effects of high dietary fiber intake in patients with type 2 diabetes mellitus. N Engl J Med. 2000;342(19):1392-8.

54. Lawlor DA, Smith GD, Ebrahim S. Hyperinsulinaemia and increased risk of breast cancer: findings from the British Women's heart and health study. Cancer Causes Control. 2004;15(3):267-75.

55. Larsson SC, Mantzoros CS, Wolk A. Diabetes mellitus and risk of breast cancer: a meta-analysis. Int J Cancer. 2007;121(4):856-62.

56. Montonen J, Boeing H, Fritsche A, Schleicher $E$, Joost HG, Schulze MB, Steffen A, Pischon T. Consumption of red meat and whole-grain bread in relation to biomarkers of obesity, inflammation, glucose metabolism and oxidative stress. Eur J Nutr. 2013:52(1):337-45.

57. Mok Y, Son DK, Yun YD, Jee SH, Samet JM. Gamma-Glutamyltransferase and cancer risk: the Korean cancer prevention study. Int J Cancer. 2016;138(2):311-9. 
58. Cohen LA. Dietary fiber and breast cancer. Anticancer Res. 1999;19(5a):3685-8.

59. Coleman HG, Murray LJ, Hicks B, Bhat SK, Kubo A, Corley DA, Cardwell CR, Cantwell MM. Dietary fiber and the risk of precancerous lesions and cancer of the esophagus: a systematic review and meta-analysis. Nutr Rev. 2013; 71(7):474-82.

60. Costabile A, Klinder A, Fava F, Napolitano A, Fogliano V, Leonard C, Gibson GR, Tuohy KM. Whole-grain wheat breakfast cereal has a prebiotic effect on the human gut microbiota: a double-blind, placebo-controlled, crossover study. Br J Nutr. 2008:99(1):110-20.

61. Foerster J, Maskarinec G, Reichardt N, Tett A, Narbad A, Blaut M, Boeing H. The influence of whole grain products and red meat on intestinal microbiota composition in normal weight adults: a randomized crossover intervention trial. PLoS One. 2014;9(10):e109606.

62. Martinez I, Lattimer JM, Hubach KL, Case JA, Yang J, Weber CG, Louk JA, Rose DJ, Kyureghian G, Peterson DA, et al. Gut microbiome composition is linked to whole grain-induced immunological improvements. ISME J. 2013;7(2):269-80.

63. Cohen LA, Zhao Z, Zang EA, Wynn TT, Simi B, Rivenson A. Wheat bran and psyllium diets: effects on $\mathrm{N}$-methylnitrosourea-induced mammary tumorigenesis in F344 rats. J Natl Cancer Inst. 1996;88(13):899-907.

64. Slavin J. Whole grains and human health. Nutr Res Rev. 2004;17(1):99-110

65. Wang D, Chuang HC, Weng SC, Huang PH, Hsieh HY, Kulp SK, Chen CS. Alpha-Tocopheryl succinate as a scaffold to develop potent inhibitors of breast cancer cell adhesion. J Med Chem. 2009;52(18):5642-8.

66. Slavin JL. Mechanisms for the impact of whole grain foods on cancer risk. J Am Coll Nutr. 2000;19(3 Suppl):300s-7s.

67. Dong JY, He K, Wang P, Qin LQ. Dietary fiber intake and risk of breast cancer: a meta-analysis of prospective cohort studies. Am J Clin Nutr. 2011;94(3):900-5.

68. Boggs DA, Palmer JR, Stampfer MJ, Spiegelman D, Adams-Campbell LL, Rosenberg L. Tea and coffee intake in relation to risk of breast cancer in the black Women's health study. Cancer Causes Control. 2010;21(11):1941-8.

69. Ogunleye AA, Xue F, Michels KB. Green tea consumption and breast cancer risk or recurrence: a meta-analysis. Breast Cancer Res Treat. 2010;119(2):477-84.

Ready to submit your research? Choose BMC and benefit from:

- fast, convenient online submission

- thorough peer review by experienced researchers in your field

- rapid publication on acceptance

- support for research data, including large and complex data types

- gold Open Access which fosters wider collaboration and increased citations

- maximum visibility for your research: over $100 \mathrm{M}$ website views per year

At BMC, research is always in progress.

Learn more biomedcentral.com/submissions 